\title{
BIOTRANSFORMATION OF VOLATILE ANAESTHETICS WITH SPECIAL EMPHASIS ON THE ROLE OF METABOLISM IN THE TOXICITY OF ANAESTHETICS
}

\author{
Russell A. VAN DYKe, PH.D. *
}

The BIOTRANSFORMATION OF DRUGs has been under investigation for less than 20 years, with most of our current knowledge of this subject coming from work in the past few years. Therefore, because of the relative newness of this field, it is not surprising to find it undergoing a great deal of change in terms of our understanding of the basic mechanisms involved as well as in the interpretation of recent findings. Many of the ideas to be presented in this discussion, while not unique, do represent a new way of considering the role of the biotransformation of drugs. This is particularly true in the case of the disposition of anaesthetics, which is one area of drug metabolism left unstudied in detail until recently and, therefore, is undergoing the most rapid changes. Before discussing the volatile anaesthetics, a few general statements regarding drug metabolism are necessary. Additional information can be found in recent publications on this subject. ${ }^{1,2}$

Three possible fates await a foreign compound, such as a drug, when it enters the body. The fate of the majority of drugs is to be metabolized by enzymes and transformed into other compounds. This enzymatic biotransformation occurs largely in the liver and to some extent in the kidneys, although most of the tissues of the body have been found to contain some enzymatic activity for this biotransformation. A second fate is to undergo a spontaneous reaction to other products, with no enzymes involved. It is important to keep in mind that both enzymatic and spontaneous reactions can occur in the course of the metabolism of a drug. As will be seen later, this probably occurs in the case of the biotransformation of the volatile anaesthetics. The third fate is to be excreted unchanged, which is an important pathway for the elimination of volatile anaesthetics as well as those compounds which are highly water soluble.

\section{Drug Metabolism}

Drugs are metabolized for various reasons but three emerge as perhaps the most important. One is related to the polarity of the drug. Most drugs are nonpolar and therefore are relatively water-insoluble or lipophilic. Drug metabolism invariably results in a more polar and thus more water-soluble compound, which is more readily excreted from the body. Secondly, drug metabolism usually results in the production of a compound devoid of the pharmacological activity of the pareni compound. This has led to the thinking that drug metabolism is a detoxi-

This investigation was supported in part by Research Grant HL-17158 from the National Institutes of Health, Public Health Service.

"Mayo Clinic and Mayo Foundation, Rochester, Minnesota. 


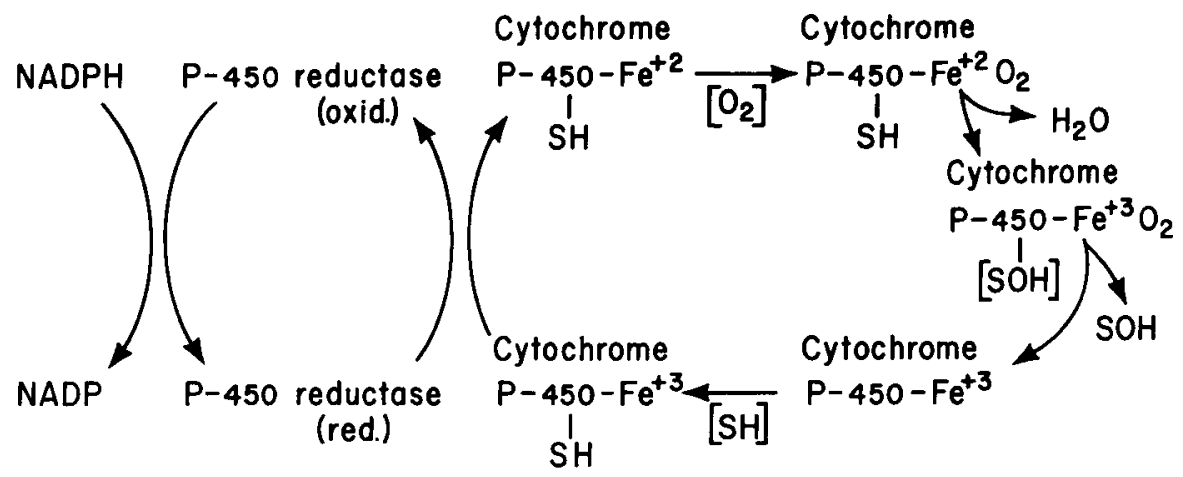

Figure 1. Scheme of events which are believed to occur in oxidation of drugs. Electrons are transferred from NADPH to cytochrome $\mathrm{P}-450$ which reduces the iron ( $\mathrm{Fe}$ ) in the cytochrome from +3 to +2 . The cytochrome, which also has bound the drug $(\mathrm{SH})$ to it, can now take up $\mathrm{O}$. and, by some unknown means, the electron and $\mathrm{O} .2$ combine to form a hydroxyl (OH) group which is then added to the drug, thereby forming an oxidized drug which is released from the cytochrome and, being more water soluble, is excreted more readily.

fication process, although with our current knowledge we know this may not be true in all cases. Thirdly, some drugs require biotransformation to produce a pharmacologically active compound.

The metabolism of drugs can be divided into two phases. Phase 1 involves a transformation consisting of an oxidation, a reduction, an hydrolysis or a combination of these. The most common transformation is oxidative, and this is the only type of phase 1 reaction which the volatile anaesthetics undergo. Phase 2 reactions involve the products of phase $\mathbf{1}$ and also drugs not subject to phase 1 attack, such as polar compounds not requiring additional polarity. These compounds undergo a synthetic reaction known as conjugation. Thus, all foreign compounds studied to date undergo some type of chemical transformation, regardless of their polarity or chemical composition.

The drug metabolizing enzyme system is found in highest concentration in the liver, with the kidneys having the next highest amount; most of the other organs of the body contain some of this activity but in much lesser amounts. Within the cell the enzyme systems are located in the various membranes, such as the cytoplasmic membrane and the endoplasmic reticulum, and may act as structural components of the membrane in addition to having enzymatic function. These membranes are rich in lipids such as steroids, phospholipids, and lipophilic proteins, which makes the membrane an ideal location for metabolism of the usually lipophilic drugs. One of the results of enzyme induction is an increase in the amount of these membranes per cell. ${ }^{3}$

The enzyme system, as we know it presently, is designed to activate molecular oxygen to some form as yet unknown. While in this form, it is transferred to the drug substrate, thereby oxidizing it. The general scheme (Figure 1) as we understand it has been discussed in recent publications. ${ }^{4.5}$

This enzyme system is called the "microsomal mixed-function oxidase system" and is completely contained within the endoplasmic reticulum or microsomes. The most important component of it is the cytochrome called "cytochrome P-450." 
Present evidence suggests that there is a multiplicity of such enzyme systems, differing only in that some cytochrome other than P-450 acts as the terminal oxidase. ${ }^{6}$ Since the cytochrome is the site to which the drug substrate binds, it is reasonable to predict that more than one cytochrome is necessary to carry out the large number of reactions assigned to this system as well as to accommodate the large number of drugs acted upon by the system.

In man this enzyme system becomes active about the time of birth. Beyond this age, environmental as well as genetic factors determine its activity. Genetic factors determine the basic amount of the system and thus account for some of the individual variation noted, while environmental factors can either enhance or inhibit this activity, accounting for additional individual variation. One of the best-studied environmental effects is enzyme induction; mentioned above as resulting in an increase in the amount of endoplasmic reticulum per cell, it also results in an increase in amount of this enzyme system per unit of endoplasmic reticulum and, therefore, in an increased rate of metabolism of drugs. ${ }^{7}$ Many chemicals, such as pesticides, certain drugs, and atmospheric pollutants, will produce this enzyme induction. ${ }^{8}$ On the other hand, the activity of this enzyme system is inhibited by many other chemicals found in our environment, resulting in a decrease in rate of drug metabolism.

The point to be considered here is that, because of the combination of genetic and environmental factors, there is a tremendous variation in rate of metabolism of drugs in any given population, although presently there is no way to predict the activity in any one individual.

The volatile anaesthetics are oxidized by one of these cytochrome-containing enzyme systems. However, the exact nature of the components of the system utilized for this reaction is not known, although it is recognized that two such systems are required to oxidize these anaesthetics - one system catalyzing the dehalogenation and the other catalyzing the ether cleavage. Presumably, each system has its own cytochrome, but neither system has been characterized to the point where a description of the cytochrome or of the mechanism involved can be given.

\section{Biotransformation of Volatile Anaesthetics}

With this brief introduction to drug metabolism, we can now direct our attention to what is known about the biotransformation of the volatile anaesthetics.

Among the possibilities of the role of biotransformation of these agents is that this metabolism limits the duration of action of anaesthetics and aids the body in removing the anaesthetic. However, there is also the possibility that biotransformation plays a role in the formation of end products or intermediate products which are toxic to certain organs. Thus, a study of biotransformation is important to understand what these products are and what conditions promote their formation. One point to be stressed is that biotransformation is not necessary for the production of anaesthesia.

Halothane $\left(\mathrm{CF}_{3}-\mathrm{CClBrH}\right)$. In spite of the fact that halothane is a relatively simple compound, not all of the information regarding its metabolism is known. The overall metabolism is as follows: 


$$
\mathrm{CF}_{3}-\mathrm{CClBrH} \stackrel{\mathrm{O}_{2}}{\longrightarrow} \mathrm{CF}_{3}-\mathrm{COOH}+\mathrm{Br}^{-}+\mathrm{Cl}^{-} \text {. }
$$

The reaction has been followed in vitro in liver preparations and in vivo in a number of species, including man. Man is one of the species most capable of carrying out this reaction, since the rate of conversion of halothane to trifluoroacetic acid and bromide is much higher than in the other species studied. Rehder, Forbes, Alter, Hessler, and Stier ${ }^{9}$ found 16 per cent to 20 per cent and Cascorbi, Blake, and Helrich ${ }^{10}$ found up to 25 per cent metabolism in 24 hours in humans, while rats metabolize only about 2 per cent to 4 per cent of a given dose in 24 hours. ${ }^{11}$

While shown as a one-step reaction, the conversion of halothane to trifluoroacetic acid may not be that simple. This point will be discussed in detail later; there may be transient intermediates which have not yet been identified.

Other products of halothane metabolism, such as the conjugates of trifluoroacetic acid, have been found in urine, as has an interesting compound, trifluoroacetylethanolamine. ${ }^{12}$ The mechanism of formation of this compound has not been discovered, nor has its importance in the overall breakdown of halothane been assessed.

In the biotransformation of halothane dehalogenation occurs, but only the chlorine and bromine are removed; the fluorine is not removed. ${ }^{11,13}$ This reflects the stability of the trifluoromethyl group to enzymatic or nonenzymatic attack.

Methoxyflurane $\left(\mathrm{CH}_{3}-\mathrm{O}-\mathrm{CF}_{2}-\mathrm{CCl}_{2} \mathrm{H}\right)$. Methoxyflurane is biotransformed in a more complex manner than halothane, because there are two sites on the molecule which can be attacked enzymatically. The ether and the carbon carrying the two chlorines requires different enzyme systems. ${ }^{14}$ The following metabolites have been found in human urine after the administration of methoxyflurane: inorganic fluoride, dichloroacetic acid, methoxydifluoroacetic acid, and oxalic acid. ${ }^{15}$ Based on these products, the route of breakdown of methoxyflurane is as follows:

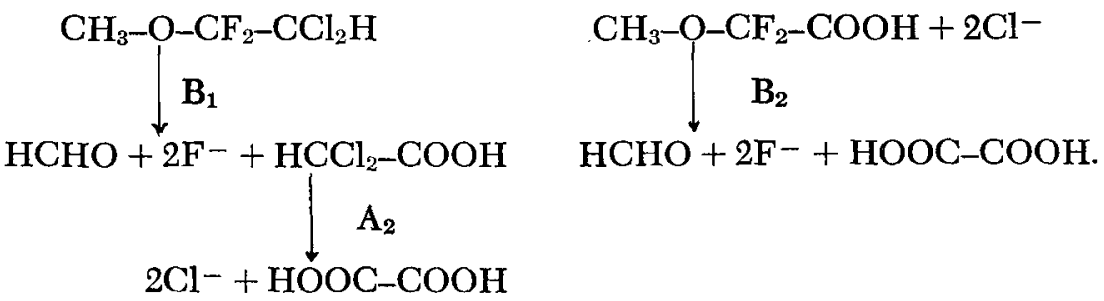

As indicated in this scheme, inorganic fluoride is released whenever the ether is cleaved; when both ether cleavage and dechlorination occur, oxalic acid is the product. The letters do not refer to the sequence but merely indicate that the A reaction is a dechlorination and the $B$ reactions are ether cleavages. It is possible that there is a particular sequence necessary for complete metabolism of methoxyflurane to oxalic acid, but this is not known at present. The formaldehyde formed in this scheme is probably quickly oxidized to $\mathrm{CO}_{2}$ and does not accumulate. The $A_{1}$ reaction is the same type of reaction that halothane undergoes when it is dehalogenated and, therefore, even though this reaction is shown as a single step, it is likely that there are one or two intermediate steps involved. 
Fluoroxene $\left(\mathrm{CF}_{3}-\mathrm{CH}_{2}-\mathrm{O}-\mathrm{CH}=\mathrm{CH}_{2}\right)$. This agent has not been studied to the extent that halothane and methoxyflurane have, but some information is available largely from the work of Blake, Rozman, Cascorbi, and Krantz. ${ }^{16}$ The following is a scheme for its metabolism:

$$
\mathrm{CF}_{3}-\mathrm{CH}_{2}-\mathrm{O}-\mathrm{CH}=\mathrm{CH}_{2} \stackrel{\mathrm{O}_{2}}{\longrightarrow} \mathrm{CF}_{3}-\mathrm{COOH}+2 \mathrm{CO}_{2} \text {. }
$$

As in the case of halothane, trifluoroacetic acid is the major product, although it is probably not produced in a single step. The intermediate steps are not known with certainty but, when an ether is cleaved, the usual products are an aldehyde and an alcohol. Therefore, it is highly likely that trifluoroacetaldehyde is an intermediate in this biotransformation. Also, as in the case with halothane, no inorganic fluoride is produced, indicating the stability of the trifluoromethyl group.

Enflurane $\left(H C F_{2}-O-C F_{2}-C F C l H\right)$. There have been few studies on the metabolism of this agent but those which have been completed indicate that a small amount of inorganic fluoride appears as product. ${ }^{17}$ While it is not known which fuorines are released from the molecule, the evidence suggests that it is the one from the $\beta$ carbon of the ethyl portion. Thus, the reaction would appear to be similar to one of the reactions of methoxyflurane:

$$
\mathrm{CF}_{2} \mathrm{H}-\mathrm{O}-\mathrm{CF}_{2} \mathrm{CFClH} \stackrel{\mathrm{O}_{2}}{\longrightarrow} \mathrm{CF}_{2} \mathrm{H}-\mathrm{O}-\mathrm{CF}_{2}-\mathrm{COOH}+\mathrm{F}^{-}+\mathrm{Cl}^{-}
$$

If the ether were cleaved, much higher concentrations of inorganic fluoride would result than have been found, because the fluorines on both sides of the ether oxygen would be released, producing four moles of inorganic fluoride for each mole of enflurane metabolized. Since only small amounts of inorganic fluoride are found, it is assumed that this metabolism takes place very slowly.

Isofurane ( $\mathrm{HCF} \mathrm{F}_{2} \mathrm{O}-\mathrm{CClH}-\mathrm{CF}_{3}$ ). The limited studies with this compound indicate that isoflurane is not metabolized. ${ }^{18}$ Regardless of whether the ether bond is cleaved or the $\beta$ carbon of the ethyl portion is attacked, inorganic fluoride should be released if degradation takes place and, since this does not occur, it is assumed that no metabolism occurs. Additional studies are in progress to verify this.

Diethyl Ether $\left(\mathrm{CH}_{3}-\mathrm{CH}_{2}-\mathrm{O}-\mathrm{CH}_{2}-\mathrm{CH}_{3}\right)$. This agent undergoes enzymatic ether cleavage ${ }^{11}$ to an aldehyde and an alcohol:

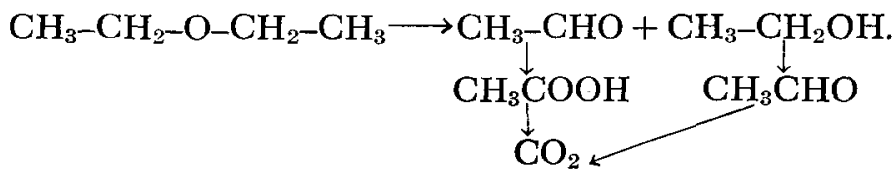

The acetaldehyde and acetic acid are intermediates in the normal metabolism of certain cellular constituents and, therefore, are readily converted to $\mathrm{CO}_{2}$

Chloroform $\left(\mathrm{HCCl}_{3}\right)$. Metabolism of this compound occurs by both enzymatic and nonenzymatic means. ${ }^{19,20}$ The mechanism of metabolism and the products are not known except that some of the carbon in the chloroform molecule eventually goes to $\mathrm{CO}_{2}$. 


\section{Role of Biotransformation of Volatile Anaesthetics in DEvelopment of TOXICITY}

Except for a few isolated examples, the biotransformations of most drugs and other chemicals foreign to the body have always been considered to be detoxification reactions. However, recent evidence indicates that this may not be the case with all chemicals. The usual method of studying drug metabolism is to examine the blood, urine, or expired air for metabolic products of the drug under study. If the metabolic products are nontoxic, it is not surprising that such a reaction is considered a detoxification. Any toxic reaction is considered to be a result of the parent compound, and little thought is given to how much of the drug remains bound in the tissue in some unknown form.

For example, chloroform and carbon tetrachloride both are metabolized to $\mathrm{CO}_{2}$ and urinary products which are nontoxic conjugates. ${ }^{20}$ The well-known toxic reactions to these compounds therefore come, not from the excreted products, but from some other source. However, the toxic reaction probably is not due to the parent molecule because the toxicity is proportional to the drug-metabolizing activity: factors which increase the microsomal enzyme activities, such as pretreatment of the animals with phenobarbital, also tend to increase the hepatotoxicity of carbon tetrachloride, ${ }^{21,22}$ and factors which inhibit microsomal enzymes tend to protect animals against the hepatotoxic effects. ${ }^{23}$ Thus, if the end-products and the parent compound are nontoxic, the toxicity must be the result of an intermediate metabolite, produced enzymatically and of transient character. ${ }^{24}$

Another example of this phenomenon is found with benzene, a known toxic compound which affects the bone marrow. It has been determined that benzene itself is not toxic but that the toxicity is proportional to the amount of metabolism. ${ }^{25}$ In addition, the products of this metabolism, while somewhat toxic, do not produce the same toxicity as benzene. Benzene toxicity is the result of an epoxide intermediate produced during the hydroxylation of benzene.

Methylcholanthrene, a polycyclic hydrocarbon, is a known carcinogen. However, its carcinogenicity is not a property of the parent compound or of the final metabolite which, while toxic to the cell, is not carcinogenic. ${ }^{26}$ Recently, the carcinogenicity of methylcholanthrene has been traced to the formation of an epoxide produced in the course of a hydroxylation reaction. Although the toxicity of methylcholanthrene bears no relationship to the toxicities of anaesthetic agents, these examples point out that intermediate metabolites are important sources of toxicity of any drug or foreign chemical.

There have been a number of instances in which metabolism of drugs has resulted in the appearance of toxic metabolites, apparently without the production of a toxic intermediate; such drugs include pyridine, sulfamerazine, and sulfadiazine. ${ }^{27}$

The metabolism of drugs can be categorized on the basis of the toxicity of the metabolites produced: (1) drugs whose metabolism results in no toxic products (probably the vast majority of drugs fall in this category); (2) drugs which are biotransformed to nontoxic metabolites but, in doing so, pass through a highly toxic intermediate stage; and (3) drugs which produce a highly toxic metabolite with or without passing through a toxic intermediate. 
The metabolites of methoxyflurane include oxalic acid, inorganic fluoride, dichloroacetic acid, methoxydifluoroacetic acid, inorganic chloride, formaldehyde, and $\mathrm{CO}_{2}$. Of these products, inorganic fluoride and oxalic acid are the best candidates as the causative agent of the nephrotoxicity due to methoxyflurane and, of these two compounds, inorganic fluoride is probably of greatest concern. Humans are capable of metabolizing large amounts of methoxyflurane and, thus, high serum fluoride levels result. Taves, Fry, Freeman, and Gillies ${ }^{28}$ have reported that the renal toxicity occurs in those persons with the highest blood fluoride level. In addition, Mazze, Cousins, and Kosek ${ }^{29}$ produced nephrotoxicity in experimental animals by administering only inorganic fluoride, although they noted strain differences in this regard.

Work in my laboratory suggests a strain difference in susceptibility to the fluoride effect on the kidney. The Fischer 344 and Sprague-Dawley strains of rats were compared in vitro for their ability to metabolize methoxyflurane to inorganic fluoride. The Fischer 344 strain had been found by Mazze et al. ${ }^{29}$ to develop polyuria after methoxyflurane administration, while the Sprague-Dawley strain did not. The urinary output of inorganic fluoride was not different between the strains, and our studies in vitro also revealed no differences either in rate of fluoride release or in total fluoride production. Thus, while a toxic metabolite is produced, it requires a susceptible enzyme for manifestation of its toxicity. Most humans presumably have in their kidneys a system susceptible to fluoride toxicity.

The role played by oxalic acid in the nephrotoxicity of methoxyflurane is not known. Theoretically, one would expect a maximal fluoride-to-oxalic acid molar ratio of 2:1, and it probably is much less than this. Therefore, it is possible that the oxalic acid levels are not high enough to affect the kidneys, although additional studies are necessary to confirm this. Thus the metabolism of methoxyflurane results in a toxic or potentially toxic product. Whether or not this metabolism proceeds through a toxic intermediate remains to be determined.

Halothane represents a different situation because of its more simplified metabolic patterns, which results in the production of trifluoracetic acid and inorganic bromide as the major metabolites. However, this raises a question as to the causative agent of the hepatotoxicity sometimes seen after halothane anaesthesia, ${ }^{\mathbf{3 0}}$ since neither trifluoroacetic acid nor bromide is toxic at the concentrations found. It is possible that the toxic agent is produced by an altered metabolic pattern in certain individuals or, as in the case of chloroform and carbon tetrachloride, there may be a toxic intermediate which accumulates in certain situations. Our working hypothesis is the latter.

In the usual method of studying drug metabolism, the products of the biotransformation are examined. Any product not readily excreted from the organism or extracted from the tissue is easily overlooked. This was particularly true in the case of the volatile anaesthetics until the work of Cohen and Hood ${ }^{31,32}$ revealed an accumulation of metabolites from halothane, diethyl ether, and chloroform in the livers of mice. These metabolites were bound to the cell constituents and were not extractable. These studies were extended in my laboratory to determine what conditions, if any, enhanced or decreased the accumulation of such metabolites from halothane. In a perfused isolated rat liver preparation, it was found that the 
accumulation of material bound to the liver was related directly to the amount of metabolism. ${ }^{33}$ Enzyme induction by phenobarbital, which enhances the metabolism of halothane, increased the amount of metabolite bound to the liver. Enzyme induction by methylcholanthrene, which does not enhance the metabolism of halothane, did not alter the binding. Chemicals known to inhibit the metabolism of halothane decreased the binding.

It is equally important that a decrease in blood flow through the liver resulted in a large increase in the amount of binding. This is a point of potential practical importance, particularly if the binding of this material is related to the development of the hepatotoxicity, since the incidence of hepatotoxicity is related to hypotensive episodes. On the other hand, decreasing the $\mathrm{P}_{\mathrm{O}_{2}}$ decreased the binding slightly, indicating a requirement for oxygen to convert halothane to the intermediate metabolite which is being bound.

We can only speculate at the present time on the importance of this binding to the development of a toxic reaction to halothane. If this binding is important, then animals which have been treated with agents known to induce the metabolism of halothane should develop this toxicity. A recent report indicates that this may be the case. ${ }^{33}$ Rats were treated with phenobarbital, a known inducer of halothane metabolism, for several days to ensure maximal enzyme induction and then were exposed to halothane. At autopsy of these animals, their livers showed a patchy centrolobular necrosis. Control animals, not given phenobarbital but exposed to halothane, showed no liver necrosis. Thus, it appears that the liver necrosis may be associated with high rate of metabolism of halothane.

Another recent report indicates that hepatotoxicity develops in guinea pigs after repeated exposures to halothane. ${ }^{34}$ Since the metabolism of halothane results in the binding of a metabolite to the cell constituents, it is conceivable that repeated doses of halothane would have an additive effect on this; with a sufficient number of exposures, a very high level of bound material would result.

The possibility that halothane hepatitis is caused by the irreversible binding of an intermediate metabolite to a cell constituent, thereby interfering with its normal function and resulting in the death of the cell, may account for the higher incidence of hepatitis in patients repeatedly exposed to halothane within a short period. Since the metabolite is irreversibly bound to the cell constituents, the only way it can be removed is by the complete breakdown of the constituent or the cell. Cell constituents have various half-lives, from hours to days, and therefore the metabolite may remain in the cell for long periods. Additional exposures to halothane would presumably have additive effects and thereby increase the concentration of the bound material and increase the possibility of destroying cells. It is also possible that hepatitis may develop from a single exposure to halothane if sufficient binding occurs. If this is the case, then not all hepatitis cases diagnosed as due to halothane are a sensitization phenomenon but may be due to a high concentration of chemical toxin. In some cases, sensitization may develop to the toxin or intermediate but, if so, this would be an additional response requiring other conditions being achieved within the cell.

It is interesting to speculate about the nature of the intermediate which may react with the cell constituents. The reaction may be visualized as follows: 


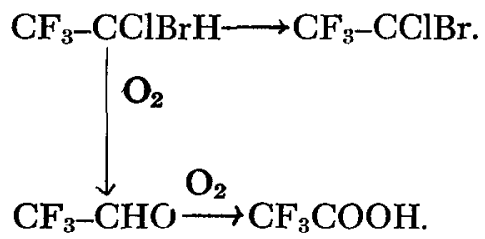

If this scheme represents what is actually happening, the two intermediates are candidates for binding with the cellular constituents. Efforts are being made to determine if this scheme is accurate.

The metabolism of fluoroxene suggests that the ether bond is cleaved and that the vinyl portion of the ether is oxidized readily to $\mathrm{CO}_{2}$ while the trifluoroethyl portion eventually is oxidized to trifluoroacetic acid, although probably not in a single step.

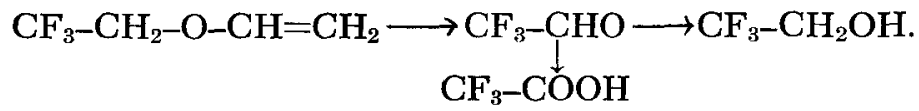

Fluoroxene has recently been implicated as a causative agent of hepatitis. ${ }^{35}$ Because this hepatitis is very much like that reported after the use of halothane, there is a strong possibility that the causative agent is the same. This idea is further strengthened by the realization that both agents may pass through the same intermediate, trifluoroacetaldehyde, a highly reactive compound. More evidence is needed to substantiate this idea.

Diethyl ether is metabolized to products which are nontoxic and easily disposed of by the cell. In addition, the formation of these products presents the cell with no known highly reactive intermediates.

Enflurane and isoflurane have not been studied sufficiently to permit discussion of the relationship of metabolism to toxicity. However, if future studies confirm that these compounds undergo little or no metabolism, it is clear that any untoward reactions are not the result of metabolism.

I think it is apparent from this discussion that no general statements can be made regarding the relationship of metabolism to the toxicity of the volatile anaesthetics. Each anaesthetic agent should be considered separately because the metabolism of each apparently involves unique relationships. As is the case with most drugs, metabolism results in products which are toxic or nontoxic, and the biotransformation occurs by way of intermediates which also may be toxic.

\section{SUMMARY}

The metabolism of drugs and other chemicals foreign to the biological system has been studied in great detail in recent years. A major portion of this study has been devoted to the nature of the enzyme system which catalyzes these biotransformations. This enzyme system is located in the membrane of cells distributed throughout the body, with the liver containing the highest amount. The name generally applied to this enzyme system, which is composed of several enzymes, is "the microsomal mixed function oxidase system." The single most important 
component of the system is cytochrome P-450, and it is on this cytochrome that the actual transformation of the drug takes place. The volatile anaesthetics are transformed by this enzyme system and, therefore, to understand the way in which these anaesthetics are metabolized, we must understand the operation of the enzyme system.

The way in which the biotransformation of the volatile anaesthetics takes place is important in assessing the relationship of the occasional untoward toxic effect of these agents to their metabolism. For halothane, a strong case can be made for an intermediate in the metabolism producing the hepatotoxicity. The same may be true for fluoroxene. The nephrotoxicity of methoxyflurane may be produced by a product of its metabolism, inorganic fluoride, although the fluoride toxicity may be enhanced by other intermediates or products of methoxyflurane metabolism. It is important that no generalizations be made concerning the relationship of metabolism to toxicity examined separately.

\section{RÉSUMÉ}

On peut considérer les médicaments comme des toxines choisies. Comme telles, elles produisent d'habitude, leur effet en inhibant ou en modifiant les réactions ou les systèmes biochimiques spécifiques. Le système ou la réaction biochimique touché peut être présent dans plusieurs organes ou sa distribution ou son influence peut être limitée à un seul organe. Dans l'une ou l'autre éventualité, la présence du médicament en concentration suffisante est tout ce qui est requis pour observer l'effet de sa toxicité sélective.

On peut observer une deuxième réaction toxique avec certains médicaments, réaction tout à fait étrangère à la première, en apparence, et se manifestant de façon imprévisible. Cette réaction indésirable se produit avec certains anesthésiques volatils - quoique ce fait ne leur soit pas réservé. Les anesthé iq.:es volatils produisent l'effet toxique immédiat : l'anesthésie, mais ils produise it également, en certains cas, plusieurs jours plus tard, des effets toxiques tout autres. La connaissance de l'élimination de ces médicaments et de leurs biotransformations pourra aider l'anesthésiologiste à faire un diagnostic différentiel en face de telles réactions.

\section{Rôle de la biotransformation dans les systèmes biologiques}

La biotransformation joue plusieurs rôles concernant l'action, le métabolisme d'un médicament. D'abord, la biotransformation est un des moyens par lequel l’organisme limite la durée d'action des médicaments. Evidemment, plus la biotransformation est rapide, plus la durée d'action est courte. La durée d'action est en relation étroite avec un deuxième facteur : la détoxification. Le rôle de détoxification est de la plus grande importance dans la biotransformation des substances chimiques étrangères qui n'ont pas d'activité pharmacologique spécifique mais qui produisent une réaction toxique. Le troisième rôle de la biotransformation - rôle d'importance limitée, mais rôle qui doit toutefois être étudié ; - c'est la biotransformation d'un produit pharmacologiquement inactif et un autre produit pharmacologiquement actif. Le quatrième rôle, également d'une importance limitée, est 
la biotransformation d'un médicament en un produit possédant des propriétés toxiques. Les recherches sur ce quatrième rôle ne font que commencer et ce rôle peut prendre une importance plus grande qu'on ne l'aurait soupçonné auparavant. Ce rôle est certainement important dans la toxicité des anesthésiques volatils.

\section{Rôle de la biotransformation en anesthésie}

La biotransformation des anesthésiques volatils ne produits pas l'anesthésie. Du fait que les produits de biotransformation ne sont pas des anesthésiques le métabolisme n'est pas nécessaire pour l'anesthésie. Ainsi, en anesthésie, le rôle du métabolisme se limite à diminuer la durée d'action et de l'intoxication possible.

\section{Rôle de la biotransformation des anesthésiques volatils dans le} développement des effets secondaires indésirables

Les substances qui produisent des effets secondaires indésirables lorsque l'halothane, le méthoxyflurane ou le fluroxene est employé ne sont pas les molécules du produit mère. Ce qui permet de raisonner ainsi, c'est que les réactions indésirables surviennent lorsque l'agent anesthésique est présent à de très faibles concentrations ou est presque disparu. Pour évaluer le rôle des produits du métabolisme comme agents responsables de ces réactions indésirables, il faut étudier chaque agent séparément. Le méthoxyflurane se métabolise en $\mathrm{CO}_{2}$, en acide méthoxydifluoroacétique, en acide dichloracétique, en acide oxalique et en fluorure inorganique. De ces produits, le fluorure inorganique et l'acide oxalique sont toxiques pour les reins, et la fluorure inorganique serait le responsable de la polyurie observée après l'administration du méthoxyflurane. Ainsi, plus il y a de méthoxyflurane de métaboliser, plus il y aura de produits toxiques.

On ne peut pas préciser aussi facilement la cause de l'hypatotoxicité observée quelquefois à la suite de l'administration de l'halothane. Le principal produit du métabolisme $\mathrm{d}$, l'halothane est l'acide trifluoracitique. Cet acide trifluoracitique ne produirait is de réaction hépatotoxique. Si l'agent toxique n'est ni l'halothane ni le produit du métabolisme de l'halothane, il doit donc être un intermédiaire dans le métabolisme de l'halothane - un produit dont l'existence est très brève mais qui est très actif et qui peut se lier étroitement aux constituants cellulaires. Des études récentes ont révélé que des portions de la molécule d'halothane étaient liées de façon irréversible aux constituants cellulaires en proportion directe au métabolisme de l'halothane et en proportion inverse au débit sanguin dans le foie. Pour confirmer l'idée qu'un produit intermédiaire du métabolisme de l'halothane se fixe dans le foie, il faut démontrer si ce produit existe en concentration suffisante et s'il entraine une réaction hépatotoxique.

\section{REFERENCES}

1. LA Du, B.N., MANDel, H.G., \& WAY, E.L. Fundamentals of drug metabolism and drug disposition. Baltimore: The Williams \& Wilkins Company (1971).

2. Vesell, E.S. [Ed.]. Drug metabolism in man. Ann. N.Y. Acad. Sci. 179: 1 (1971).

3. Orrenius, S., Ericsson, J.L.E., \& Ernster, L. Phenobarbital-induced synthesis of the microsomal drug-metabolism enzyme system and its relationship to the proliferation of endoplasmic membranes: a morphological and biochemical study. J. Cell. Biol. 25: 627 (1965). 
4. Schenkman, J.B. The effects of temperature and substrates on component reactions of the hepatic microsomal mixed-function oxidase. Mol. Pharmacol. 8: 178 (1972).

5. Cohen, B.S. \& Estabrook, R.W. Microsomal electron transport reactions. III. Cooperative interactions between reduced diphosphopyridine nucleotide and reduced triphosphopyridine nucleotide linked eactions. Arch. Biochem. Biophys. 143: 54 (1971).

6. SladeK, N.E. \& Mannering, G.J. Evidence for a new p-450 hemoprotein in hepatic microsomes from methylcholanthrene treated rats. Biochem. Biophys. Res. Commun. 24: 668 (1966).

7. Marver, H.S., Schmid, R., \& Schǘzee, H. Heme and methemoglobin: naturally occurring repressors of microsomal cytochrome. Biochem. Biophys. Res. Commun. 33: 969 (1968).

8. Conney, A.H. Pharmacological implications of microsomal enzyme induction. Pharmacol. Rev. 19: 317 ( 1967).

9. Rehder, K., Forbes, J., Alter, H., Hessler, O., \& Stien, A. Halothane biotransformation in man: a quantitative study. Anesthesiology 28: 711 (1967).

10. Cascorbi, H.F., Blake, D.A., \& Helrich, M. Differences in the biotransformation of halothane in man. Anesthesiology 32: 119 (1970).

11. Van Dyke, R.A., Chenowethi, M.B., \& Van Poznak, A. Metabolism of volatile anaesthetics. I. Conversion in vivo of several anesthetics to ${ }^{14} \mathrm{CO}_{2}$ and chloride. Biochem. Pharmacol. 13: 1239 (1964).

12. Conen, E.N. \& Trudell, J.R. The urinary metabolites of halothane. Abstracts of scientific papers, 1971, p. 21. Atlanta, American Society of Anesthesiologists (1971).

13. VAN Dyke, R.A. \& Chenoweth, M.B. The metabolism of volatile anesthetics. II. In vitro metabolism of methoxyflurane and halothane in rat liver slices and cell fractions. Biochem. Pharmacol. 14: 603 (1965).

14. VAN DYke, R.A. \& WoOn, C.L. Binding of radioactivity from ${ }^{14} \mathrm{C}$-halothane in isolated, perfused rat livers, (Unpublished data.)

15. Holaday, D.A., Rudofsky, S., \& Treuraft, P.S. The metabolic degradation of methoxyflurane in man. Anesthesiology 33: 579 (1970).

16. Blake, D.A., Rozman, R.S., Cascorbi, H.F., \& Krantz, J.C., Jr. Anesthesia LXXIV: Biotransformation of fluroxene. I. Metabolism in mice and dogs in vivo. Biochem. Pharmacol. 16: 1237 (1967).

17. VAN DYKe, R.A. \& Wood, C.L. Unpublished observations.

18. VAN DYKE, R.A. \& WoOn, C.L. Unpublished observations.

19. Van Dyke, R.A. \& Chenoweth, M.B. Discussion. In uptake and distribution of anesthetic agents. Edited by Papper, E.M. \& Kitz, R.J. p. 187. New York: Blakiston Division, McGraw-Hill Book Company, Inc. (1963).

20. Paul, B.B. \& Rubinstein, D. Metabolism of carbon tetrachloride and chloroform by the rat. J. Pharmacol. Exp. Ther. 141: 141 (1963).

21. Seawright, A.A., McLean, A.E.M., \& Forrest, D.T.M. Hepatic oxidative drug metabolism and induced susceptibility in sheep to carbon tetrachloride intoxication. Vet. Rec. 82: 200 (1968).

22. Sasame, H.A., Castro, J.A. \& Gillette, J.R. Studies on the destruction of liver microsomal cytochrome P-450 by carbon tetrachloride administration. Biochem. Pharmacol. 17: 1759 ( 1968$)$.

23. Castro, J.A., Sasame, H.A., Sussman, H., \& Gillette, J.R. Diverse effects of SKF 525-A and antioxidants on carbon tetrachloride-induced changes in liver microsomal P-450 content and ethylmorphine metabolism. Life Sci. [I] 7: 129 (1968).

24. McLean, A.E.M. \& MCLEAN, E.K. The effect of diet and 1,1,1-trichloro-2,2-bis-( $p$-chlorophenyl)ethane (DDT) on microsomal hydroxylating enzymes and on sensitivity of rats to carbon tetrachloride poisoning. Biochem. J. 100: 564 (1966).

25. Mitchele, J.R. Effect of drugs on aromatic hydrocarbon-induced aplastic anemia. Abstracts of the 1971 Pharmacology-Toxicology Program Symposium.

26. Huberman, E., Asptras, L., Heidelberger, C., Grover, P.L., \& Sims, P. Mutagenicity to mammalian cells of expoxides and other derivatives of polycyclic hydrocarbons. Proc. Natl. Acad. Sci. U.S.A. 68: 3195 (1971).

27. Willuams, R.T. Detoxification mechanisms: the metabolism and detoxification of drugs, toxic substances and other organic compounds. New York: John Wiley \& Sons, Inc. (1959).

28. Taves, D.R., Fry, B.W., Freeman, R.B., \& Gill.jes, A.J. Cited by Mazze, R.I.; Trudell, J.R., \& Cousins, M.J. Methoxyllurane metabolism and renal dysfunction: clinical correlation in man. Anesthesiology 35: 247 (1971). 
29. Mazze, R.I., Cousins, M.J., \& Kosek, J.C. Dose-related methoxyflurane nephrotoxicity in rats: a biochemical and pathologic correlation. Anesthesiology 36: 571 (1972).

30. Carney, F.M.T. \& VAN DYke, R.A. Halothane hepatitis: a critical review. Anesth. Analg. (Cleve.) $51: 135(1972)$.

31. Conkn, E.N. \& Hood, N. Application of low-temperature autoradiography to studies of the uptake and metabolism of volatile anesthetics in the mouse. II. Diethyl ether. Anesthesiology 31:61 (1969).

32. CoHen, E.N. \& Hood, N. Application of low-temperature autoradiography to studies of the uptake and metabolism of volatile anesthetics in the mouse. I. Chloroform. Anesthesiology 30: 306 (1969).

33. Stenger, R.J. \& Johnson, E.A. Induction of halothane hepatotoxicity by phenobarbital pretreatment (abstract). Gastroenterology 62: 167 (1972).

34. Hughes, H.C., Jr. \& LANG, G.M. Hepatic necrosis produced by repeated administration of halothane to guinea pigs. Anesthesiology $36: 466$ (1972).

35. Reynolds, E.S., Brown, B.R., Jr., \& VANDAM, L.D. Massive hepatic necrosis after fluroxene anesthesia - a case of drug interaction? N. Engl. J. Med. 286: 530 (1972). 